\title{
DINAMIKA PEMBELAJARAN BERBASIS TEKNOLOGI INFORMASI PADA LEMBAGA PENDIDIKAN TINGGI
}

\author{
Oleh : Usman \\ Dosen STAIN Parepare Jurusan Tarbiyah dan Adab \\ Mahasiswa Pendidikan dan Keguruan Program Doktor Pasca Sarjana UINAM \\ Email : usmannoer@gmail.com
}

\begin{abstract}
Seiring dengan kemajuan zaman, penerapan teknologi modern dan kekinian semakin digalakkan dalam berbagai sektor kehidupan, termasuk dalam dunia pendidikan dan pembelajaran baik di kelas konvensional maupun di luar kelas secara online, sehingga diharapkan bahwa semakin modern teknologi tersebut maka semakin mudah bagi para pendidik dalam dalam mencapai tujuan pembelajarannya. Pembelajran bebasis teknologi informasi pada lembaga pendidikan tinggi telah menjadi perhatian serius bagi pengelola lembaga pendidikan, sebab bila lembaga pendidikan terutama lembaga pendidikan tinggi tidak menerapkan atau mengaplikasikan program pembelajaran online dengan dukungan teknologi terkini maka perguruan tinggi tersebut akan tergeser dan ditinggalkan oleh para peserta didiknya. Program pembelajaran berbasis teknologi informasi dengan berbagai dinamikanya menjadikan pembelajaran semakin menarik dan menantang, karena peserta didik dan pendidik tidak lagi dibatasi oleh ruang dan waktu sebagaimana dalam pembelajaran konvensional dalam proses pembelajarannya. Pembelajaran kini menggunakan media komputer berbasis online yang aplikasinya biasa disebut e-learning atau web-learning.
\end{abstract}

\section{Keywords : \\ Pembelajaran, Teknologi Informasi dan e-learning.}

\section{Pendahuluan}

Pemanfaatan Teknologi Informasi dalam bidang pendidikan, khususnya dalam bidang pembelajaran sebenarnya merupakan mata rantai dari sejarah teknologi pembelajaran. Sejarah pembejaran berbasis komputer dimulai dari munculnya ide-ide untuk menciptakan perangkat teknologi terapan yang memungkinkan seseorang melakukan proses belajar secara individual dengan menerapkan prinsip-prinsip didaktik-metodik. Sejarah teknologi pembelajaran ini sendiri merupakan kreasi berbagai ahli dalam bidang terkait, yang pada dasarnya ingin berupaya mewujudkan pembelajaran yang menekankan perbedaan individual, baik dalam kemampuan maupun dalam kecepatan berpikir dan berkreasi.

Perwujudan ide-ide praktis itu juga sejalan dengan perkembagan teori-teori belajar yang dikembangkan oleh para ahli psikologi yakni dari berkembangnya teori belajar behaviorisme 
(aliran belajar tingkah laku) dan teori kognitif, terutama yang menekankan model pemerosesan informasi, termasuk juga perkembagan teori belajar tuntas atau mastery learning.

Teknologi informasi telah berkembang seiring dengan perkembagan era kekinian sehingga interaksi dan penyampaian informasi akan berlangsung dengan sangat cepat, mengakibatkan pertukaran informasi, ilmu pengetahuan dan pemanfaatan media digital menjadi kebutuhan hampir semua manusia sehingga butuh persaingan untuk mendapatkannya. Persaingan mengakibatkan terjadinya digital-divide (perbedaan yang mecolok) dalam mengakses teknologi sehingga menuntut adanya pengembangan mutu dan kualitas sumber daya manusia sebagai produdusen dan pengguna teknologi. Pendidikan adalah salah satu hal penting dalam pengembangan sumber daya manusia dan bagi para praktisi pendidikan, hal ini menjadi tantangan dalam meningkatkan mutu sistem pendidikan.

Pada sektor pendidikan, melalui kebijakan pemerintah atas penggunaan Information Communicatin and Tehnology (ICT) didasarkan pada Kepres No. 50/2000 tentang pengadaan Tim Koordinasi Telematika Indonesia, ${ }^{1}$ telah memanfaatkan ITC dalam pendidikan yang dikenal dengan e-education.

Dalam pelaksanaannya, ada satu kelompok kerja yang bertanggung jawab untuk mengembangkan program e-ducation dibawah naungan Kementerian Pendidikan Nasional dengan menetapkan tujuan sebagai berikut:

1. Mengembangkan ICT network untuk umum dan unversitas seperti riset dan pendidikan network.

2. Mempersiapkan suatu rancangan pengembangan sumber daya manusia dalam mengaplikasikan ICT

3. Mengembangkan dan menerapkan kurikulum berbasis ICT

4. Menggunakan ICT sebagaisuatu bagian dari kurikulum pembelajaran di sekolah, unversitas dan pusat-pusat pelatihan.

5. Mengadakan program yang berhubungan dnegan pendidikan yakni mengikut sertakan sekolah dalam pembelajaran seluas-luasnya.

\footnotetext{
${ }^{1}$ Telematika dalah kepanjangan dari Teknologi Komunikasi, Media dan Informatika yang mengacu pada pemanfaatan ICT dalam berbagai sektor dan aspek kehidupan, Lihat; Rusman, Model-Model Pembelajaran, Mengembangkan Profesionalisme Guru, (Cet. 3; Jakarta: PT. Raja Grafindo Persada, 2011), h. 285
} 
6. Memfasilitasi penggunaaan internet dengan efisien dalam proses pembelajaran. ${ }^{2}$

E-education, berhubungan dengan pemanfaatan media komunikasi dan teknologi informasi, seperti komputer, internet, telepon, media audio visul dan alat bantu lainnya yang dikemas dalam bentuk program pembelajaran e-learning pada berbagai level pendidikan.

Sampai akhir dekade 90-an, penyelenggaraan pembelajaran termasuk perkuliahan, cukup dikelola dengan memberlakukan metode pembelajaran mahasiswa akatif. Lalu pada tahuan 2000-an telah diterapkan atau telah diberlakukan kurikulum berbasis kompetensi. Peserta didik dikondisikan supaya aktif dengan cara memberikan tugas mandiri terstruktur. Setiap kali pertemuan kelas, mereka tidak sekedar datang dengan tatapan kosong tetapui membawa sejumlah temuan yang akan dikonfirmasikan dengan pendidiknya, sayangnya metode ini tidak berjalan maksimal pada leven pendidikan S1. Mahasiswa seringkali datang tanpa persiapan maksimal bahkan tidak sedikit dari mereka yang hanya datang, duduk, diam dan dengar (3D). Untuk membuat mahasiswa aktif, ternyata tidak cukup dengan membangkitkan semangat peserta didik untuk belajar, namun diperlukan kreatifitas tinggi dari pendidiknya termasuk kreatifitas dalam pembelajaran oleh para dosen. Untuk itu penggunakan IT dalam pembelajaran merupakan terobosan baru dalam meningkatkan kemanpuan pemahaman peserta didik dan juga untuk menciptakan suasana belajaran yang nyaman dan menyenangkan sehingga dapat memberikan motivasi kepada perserta didiknya.

Berkat perkembangan teknologi informasi, pada awal tahun 2000-an e-lerning hadir memberikan pembaruan pola perkuliahan yang mencengangkan karena berbeda dengan format konvensional berupa pertemuan kelas yang dianggap menjemukan. Perkuliahan tidak lagi hanya terbatas pada pertemuan di kelas yang berhenti ketika kelas selesai, artinya berakhirnya pertemuan di kelas semestinya hubungan komunikasi antara dosen dan mahasiswanya telah berhenti, tetapi komunikasi harusnya tetap berjalan. Bila pertemuan kelas baru bisa terjadi jika dosen dan mahasiswa sepakat bertemu pada waktu yang sama sesuai dengan jadwal mata kuliahnya yang kaku, pertemuan di e-learning penjadwalannya lebih fleksibel karena pertemuan bisa terjadi pada waktu dan tempat yang berbeda, pada e-learning, mahasiwa bisa bertemua dengan temannya dan dosennya kapan saja. 
Berkaitan dengan pemanfaatan e-learning difokuskan pada penggunaan komputer sebagai medianya, telah menjangkau berbagai kepentingan termasuk pembelajaran yakni membantu tenaga pendidik dalam meningkatkan mutu pembelajarannya secara komprehensip, yang dalam penerapannya pengguanaan komputer dapat dibagi atas dua yakni: pertama, bentuk pembelajaran dengan bantuan komputer (Computer Assisted Instruction=CAI) dan kedua, pembelajaran berbasis komputer (Computer Based Instruction=CBI). Dalam banyak hal kedua penerapan dalam pemanfaatan komputern untuk pembelajaran ini sama, perbedaan yang menonjol diantara keduanya terletak apda fungsi perangkat lunak yang digunakan. Pada CAI perangkat lunak yang digunakan berfungsi membantu pendidik dalam proses pembelajaran, seperti sebagai multi media, alat bantu dalam presentasi maupun demonstrasi atau sebagai alat bantu dalam pelaksanaan pembelajaran. Sedangkan pembelajaran berbasis komputer (CBI) mempunyai fungsi yang lebih luas. Perangkat lunak dalam CBI selain dapat digunakan sebagai fugnsi CAI, juga dapat dimanfaatkan sebagai sistem pembelajaran individual. Pada CBI pendidik berperan sebagai desainer dan programer pembelajaran.

Penggunaan ICT dalam dunia pendidikan dikenal dengan program e-learning, yang notebene telah dikembangkan di bawah naungan program telematikan pendidikan dan diimplementasikan pada segala bentuk teknologi komunikasi untuk menciptakan, mengelola dan memberikan informasi pada pembelajaran.

Meskipun penggunaan IT dalam proses pembelajaran memiliki kelebihan dibandingkan dengan pertemuan kelas secara konvensional, eksistensinya tidak serta merta dapat diterima dengan mudah baik dikalangan mahasiswa maupun di kalangan para dosen. Dosen menerima atau menolak, tergantung pada paradigmanya dalam memanage mata kuliah. Setidaknya ada dua paradigma yang antagonistik (saling betolak belakang) yakni pro status quo (the state in which) mempertahankan keadaan yang sudah ada, atau setuju dengan keadaan yang ada pada saat ini. Pada tataran ini, paradigma dosen yang hanya menerima keadaan bahwa apa yang ada sudah lebih dari cukup dan perlu untuk terus di langgengkan tanpa perlu menghiraukan perubahan yang terjadi, walupun perubahan itu lebih maju dan moderen dari sebelumnya, bahkan setiap usaha pembaruan dicurigai sebagai antiestablishment yang hanya akan mengganggu jalannya pembelajaran yang sudah bisa diterima dengan baik oleh kalangan pendidik maupun perserta didik. Pembaruan hanya akan mengakibatkan destabilitas kemapanan perkuliahan yang berujung pada konflik yang pada 
akhirnya bermuara pada perpecahan. Jika ini terjadi semuanya akan merugi, baik dosen selaku pendidik, maupun mahasiswa selaku peserta didik, karena tujuan perkuliahan akan sulit tercapai.

Bagaikan sisi mata uang, paradigma pro status qua melatar belakangi paradigma prochange atau sering disebut pro-perubahan. Pola atau manajemen perkuliahan yang diterapkan selama ini yang membuat dosen merasa nyaman diperlukan adanya inovasi yang berarti mengenyampingkan atau meninggalkan pola lama yang konservatif tradional yang ada selama ini, tetapi lebih menekankan pada perbaikan pola yang telah ada, maksudnya adalah bahwa pola konvensional yang sudah lama ada terkait dengan manajemen mata kuliah tetap dipelihara atau dilestarikan, tetapi tidak menutup kemungkinan untuk beradaptasi dengan pola baru yang ternyata banyak memberi manfaat dan kebaikan terhadap sistem lama. Berbeda dengan pro-status quo yang berpendapat bahwa adopsi sistem baru bisa berdampak pada destabilitas kemapanan, pro-change beranggapan bahwa dampak yang terjadi bukannya destabilitas tetapi dinamika. Pola dinamis itu selalu berkembang dan berubah sesuai dengan tuntutan dunia luar yang berbeda dengan pola statis yang selalu mengidolakan kemapanan terhadap sistem yang ada sekaligus bersikap apatis terhadap perubahan. Bagi dosen yang berparadigma pro-change, mereka akan terus berinovasi supaya perkuliahan benar-benar efektif dan efisien sesuai indikator perkuliahan yang sudah dari awal ditentukan dalam bentuk silabus maupun course outline (satuan acara perkuliahan).

Senada dengan yang dikemukakan oleh Durkheim bahwa: pro-change berkerja secara "organik" yang tidak hanya sebatas apa yang diperintahkan melainkan juga selalu berinovasi bahkan berimprovisasi terhadap pekerjaannya. Sebaliknya, mereka yang pro-status quo hanya bekerja "mekanik" sesuai dengan yang diperintahkan atasan tanpa pernah berinovasi apalagi berimprovisasi. $^{3}$

Dua paradigma di atas berpengaruh pada perlu tidaknya e-learning diberlakukan dalam perkuliahan. Mereka yang pro-change tidak hanya menerima (welcome) tetapi bahkan merayakan (celebrate) kehadiran e-learning. Karena e-learning menawarkan pembaruan perkuliahan yang tidak ditemui di model atau metode perkuliahan konvensional. Sebaliknya, mereka yang pro-status quo yang merasa sudah mapan dengan model atau metode perkuliahan konvensional memandang tidak diperlukannya e-learning dengan berbagai alasan yang dicari-

${ }^{3}$ Emile Durkheim, The rules of Sosiological Method, (New York: The Free Press; 1938), h. 40 
cari (miskuiding reasoning). Alasan yang sering mereka ajukan seperti: (1) e-learning akan menggantikan peran dosen, (2) e-learning tidak humanis karena pertemuan dosen dan mahasiswa tidak terjadi secara lansung, (3) e-learning membuat dosen dan mahasiswa malas masuk kelas dan (4) sudah ada blog mengapa harus repot-repot menggunakan e-learning. Resistensi terhadap e-learning lebih disebabkan oleh karena dosen tidak mendapatkan informasi yang memadai dan tuntas tentang e-learning, sehingga pemahamannya terhadap $e$ learning tidak komprehensif apalagi mengalami sendiri (eksperiential learning) apa sebenarnya e-learning itu. Ini yang disebut dengan sikap apatis terhadap perubahan.

"Bagi siapa saja yang tidak mau berubah akan digilas oleh zaman," begitu kata orang bijak. Apakah kata-kata ini juga berlaku bagi perguruan tinggi yang tidak mengaplikasikan $e$ learning? Kita bisa mengkilas balik tahun 80-an untuk mengirim pesan tertulis supaya cepat diterima oleh orang yang dituju diperlukan media telegram yang ongkosnya dihitung per karakter dari kata-kata yang digunakan dalam telegram. Maka pesan yang dikirimkan mesti straight forward (singkat dan tepat). Telegram yang sangat berjasa waktu itu mulai ditinggalkan pada awal 2000-an karena muncul media yang fungsinya sama tetapi bisa menyampaikan pesan lebih cepat ke tempat tujuan dengan ongkos yang sangat murah bahkan gratis, yaitu media SMS. Begitu juga dengan wartel (warung teleko-munikasi). Di tahun 1990an hingga awal 2000-an wartel seperti magnet dengan daya serap yang sangat kuat terutama bagi mereka yang berpisah dari keluarga untuk tetap menjaga komunikasi. Antrian ke wartel begitu mengular ketika masuk pada jam 9 malam sampai dengan jam 6 pagi karena tersedianya layanan telepon murah. Mulai akhir tahun 2000-an sudah mulai jarang usaha wartel apalagi sekarang ini hampir tidak ada satupun usaha wartel yang dulu ramai disepanjang jalan yang kita lalui. Maka sejak itu muncullah warnet (warung internet) yang hingga sekarang masih bertahan meskipun lambat laun peran warnet akan digantikan oleh kehadiran smartphone.

Perubahan adalah sebuah keniscayaan (hukum alam) dan mengikuti perkembangan manusia beserta lingkungan sosialnya. Perubahan dari telegram ke sms dan dari wartel ke warnet inilah yang disebut dengan to turn challenge into opportunity yang berarti perubahan zaman yang selalu menantang dan beresiko itu bisa memberikan peluang dan kesempatan bagi kita untuk berkembang dan maju. Skenario yang sama sangat mungkin terjadi di perguruan tinggi. Ketika telah ada model pembelajaran baru tetapi masih asyik menggunakan metode 
pembelajaran lama yang konvensional tanpa berbenah dengan mengadopsi metode pembelajaran baru yang lebih efektif dan efisien, maka gilasan sejarah dalam bentuk likuidasi perguruan tinggi hanya menunggu waktu. Sebaliknya, perguruan tinggi yang tertantang dengan adanya e-learning dan sesegera mungkin menerapkannya kedalam sistem pembelajaran, maka e-learning bisa menjadi daya tarik bagi para stakeholders karena sejalan dengan tuntutan masyarakat di era digital dan informasi.

Kenyataan menunjukkan bahwa pola perubahan yang terjadi dalam lembaga pendidikan dengan menggeliatnya pembangunan infra struktur perkuliahan semakin menunjukkan kemapanan dalam persaingan pendidikan termasuk lembaga pendidikan tinggi secara lokal dan nasional. Pembangunan gedung perkuliahan dan perkantoran semakin digalakkan, sehingga sudah semestinya juga mengedepankan keunggulan para tenaga pengajarnya dan juga tenaga kependidikannya untuk dapat menguasai ilmu pengetahuan dan teknologi moden dalam proses pembelajaran.

Untuk itulah perlunya kegiatan pelatihan pembelajaran bagi seluruh Dosen secara berkala dengan menhadirkan pembicara yang memang ahli dalam bidang pembelajaran dengan kemampuan penguasaan Teknologi IT mulai dari pengenalan Program Microsoft dalam hal ini peningkatan kemampuan membuat file presentasi (Power Point), Browsing Informasi lewat Internet, Pembelajaran Website, E-mail dan pemanfaatan penggunaan media Pembelajaran berbasis LCD serta yang terakhir adalah pemanfaatan penggunaan Pembelajaran berbasis e-learning.

\section{Pembahasan}

\section{Teknologi Pembelajaran Berbasis IT}

\section{a. Teknologi Komputer}

Teknologi pembelajaran berbasis komputer pada awalnya diperkenalkan oleh Sydney L. Pressey tahun 1960 yang menciptakan mesin mengajar (teaching machine), sehingga karya tersebut dapat dianggap sebagai pelopor dalam pemanfaatan teknologi dalam pembelajaran.

Cara kerja mesin mengajar tersebut adalah : 1) bahan disusun dalam bentuk pertanyaan pilihan ganda dengan empat kemungkinan jawaban, dengan satu diantaranya 
adalah jawaban yang benar; 2) testee membaca soal tes pada layar display dan memilih alternatif jawaban yang benar dari satu soal; 3) dengan menekan tombol alternatif jawaban yang benar, maka pada layar display akan muncul soal berikutnya. Tetapi bila salah maka akan memberikan respon dengan cara tidak memunculkan soal berikutnya. ${ }^{4}$

Walaupun pada awal penggunaan teknologi pembelajaran berbasis komputer ini hanya terbatas pada saat pemberian evaluasi, namun dalam perkembangan selanjutnya teknologi ini ternyata dimanfaatkan pula dalam proses pembelajaran.

Berdasarkan pemanfaatan pembelajaran berbasis komputer yang diaplikasikan oleh salah seorang ahli dalam bidang pembelajaran yakni ahli psikologi dari aliran behavioristik yang ternama; B.F Skinner yang menciptakan pembelajaraan terprogram (programmed instruction). Sistem pembelajaran terprogram memungkinkan interakski peserta didik dengan perserta didik lainnya dan iteraksi peserta didik dengan pendidiknya yang dilakukan secara langsung, tetapi melalui program yang dapat berbentuk tulisan, rekaman audio, film, mesin mengajar, dan semacamnya, sehingga proses pembelajaran tetap terlaksana walaupun obyek dan subyek pembelajar tidak berada pada tempat yang sama.

Pembelajaran berbasia komputer ini juga dipengaruhi oleh teori belajar kognitif model pemerosesan informasi (information processing modle). Model ini menampilkan konseptualisasi dari sistem memori pada manusia yang mirip dengan sistem memori pada komputer. Adapun model-model pembelajaran berbasis komputer dapat diklasifikasi dalam 4 model. Tiga di antaranya yaitu :

1) Model Drills

Model Drills adalah suatu model dalam pembelajaran dengan jalan melatih siswa terhadap bahan pelajaran yang sudah di berikan. Melalui model drills akan ditanamkan kebiasaan tertentu dalam bentuk latihan. Model drills dalam pembelajaran berbasis komputer pada dasarnya merupakan salah satu model pembelajaran yang bertujuan memberikan pengalaman belajar yang konkret melalui penciptaan tiruantiruan bentuk pengalaman yang mendekati suasana yang sebenarnya.

Hal ini sesuai dengan karakteristik pada drills dalam pembelajaran berbasis komputer yang dasarnya merupakan salah satu model pembelajaran yang bertujuan 
memberikan pengalaman belajar yang lebih konkret melalui penyediaan latihan-latihan soal yang bertujuan untuk menguji performance dan kemampuan siswa melalui kecepatan penyelesaian soal-soal latihan yang diberikan program CBI.

Berdasarkan uraian di atas dapat diambil benang merahnya bahwa secara umum tahapan penyajian model drills adalah sebagai berikut:

- Penyajian masalah-masalah dalam bentuk latihan soal pada tingkat tertentu dari kemampuan dan performance siswa.

- Siswa mengerjakan soal-soal latihan.

- Program merekam penampilan siswa, mengevaluasi, kemudian memberikan umpan balik.

- Jika jawaban yang diberikan siswa benar program menyajikan materi selanjutnya dan jika jawaban siswa salah program menyediakan fasilitas untuk mengulangi latihan (remedial) yang dapat diberikan secara parsial atau pada akhir keseluruhan soal. $^{5}$

Program pembelajaran berbasis komputer merupakan program pembelajaran yang digunakan dalam proses pembelajaran dengan menggunakan software komputer berupa program komputer yang berisi materi pelajaran dalam bentuk latihan-latihan. Hal itu sejalan dengan apa yang dikemukakan oleh Robert Heinich, Molenda, dan James D.Russel, yang menyatakan bahwa :

"Computer system can delivery instruction by allowing them to interact with the lesson programmed into the system; this is refered to computer based instruction". ${ }^{6}$

Pernyataan tersebut dapat di manefestasikan sebagai sistem komputer dilaksanakan untuk menyampaikan pembelajaran secara individual dan langsung kepada para siswa dengan cara berinteraksi dengan mata pelajaran yang diprogramkan ke dalam sistem komputer, inilah yang disebut dengan pembelajaran berbasis komputer.

Melalui sistem komputer kegiatan pembelajaran dilakukan secara mastery learning, maka guru dapat melatih siswa secara terus menerus sampai mencapai

\footnotetext{
${ }^{5}$ Rusman, Model-Model Pembelajaran, Mengembangkan Profesionalisme Guru, h. 292

${ }^{6}$ Robert Heinich, Melonda, M. \& Rossel, J.D, Instructional Technology for Teaching and Learning: Designing Instruction, Integrating Computers and Using Media, $3^{\text {rd }}$ Edition (Londen: Routledge; 1996), h. 226
} 
ketuntasan belajar. Latihan yang diberikan guru dimaksudkan untuk melatih keterampilan siswa dalam menggunakan komputer terutama dalam pelaksanaan pembelajaran yang dilakukan.

2) Model Tutorial

Konsep dasar program tutorial sama dengan program bimbingan yakni dengan tujuan memberikan bantuan kepada peserta didik agar dapat mencapai hasil belajar secara optimal. Kegiatan ini sangat dibutuhkan sebab peserta didik yang dibimbing melaksanakan kegiatan belajar mandiri dengan menggunakan modul-modul dalam bidang studi tertentu, sehingga kegiatan ini berkaitan dengan program pembelajaran modular yang dikombinasikan dengan jaringan internet sehingga berbasis pembelajaran sistem jarak jauh, programnya banyak sekali ditawarkan melalui kegiatan dunia maya, salah satu diantaranya dengan program moddle yakni program komputer berbasi website melalui e-learning.

Pembelajaran berbasis e-learning menggunakan aplikasi moodle memungkinkan peserta didik untuk masuk ke dalam kelas virtual (virtual classroom) untuk mengakses materi-materi pembelajaran. Dengan mengguakan aplikasi ini, kita dapat membuat materi pembelajaran, kuis, jurnal elektronik dan lain sebagainya secara online.

Tutorial didefinisikan sebagai bentuk pembelajaran khusus dengan pembimbing yang terkualifikasi, penggunaan micro computer untuk tutotial pembelajaran. Tutorial dengan metode alternative diantaranya bacaan, demonstrasi, penemuan bacaan, atau pengalaman yang membutuhkan respon secara verbal dan tulisan serta adanya ujian.

Program tutorial merupakan program pembelajaran yang digunakan dalam proses pembelajaran menggunakan software berupa program komputer yang berisi materi pelajaran dan soal-soal latihan. Adapaun fungsi tutorial yaitu; fungsi Kurikuler, Pembelajaran, Diagnosis bimbingan, Administratif dan fungsi Personal.

Sedangkan tujuan pembelajaran tutorial adalah sebagai berikut; Untuk meningkatkan penguasaan pengetahuan para siswa, untuk meningkatkan kemampuan dan keterampilan siswa tentang cara memcahkan masalah, untuk meningkatkan kemampuan siswa tentang cara belajar mandiri dan penerapannya.

Tahapan atau langkah-langkah pembelajaran berbasis komputer model tutorial adalah sebagai berikut: 
a. Penyajian informasi (presentation of informations), yaitu berupa materi pelajaranyang akan dipelajari peserta didik

b. Pertanyaan dan respons (quetion of responses), yaitu berupa soal-soal latihan yang harus dikerjakan oleh peserta didik

c. Penilai respons (judging of responses), yaitu komputer akan memberikan respons terhadap kinerja dan jawaban peserta didik

d. Pemberian balikan respons (providing feedback about responses), yaitu setelah selesai, program akan memberikan balikan, apak telah suskses/ berhasil atau harus mengulang.

e. Pengulangan (remediation)

f. Segmen pengaturan pelajaran (sequencing lesson segment $)^{7}$.

Berdasarkan uraian di atas, dapat diambil benang merahnya bahwa pembelajaran tutorial bertujuan untuk memberikan kepuasan atau pemahaman secara tuntas bagi peserta didik mengenai materi yang sedang dipelajari, dan oleh karenanya terdapat beberapa hal yang menjadi identitas dari tutorial yaitu pengenalan, penilaian respons, pemberian umpan balik tentang respons, pembetulan, segmen pengaturan pembelajaran dan kegiatan penutup.

3) Model Simulasi

Model simulasi dalam pembelajaran berbabasi komputer adalah model yang menampilkan materi pelajaran yang dikemas dalam bentuk simulasi-simulasi pembelajaran dengan membuat animasi yang menjelaskan konten secara menarik, hidup dan memadukan unsur teks, gambar, audio, gerak dan paduan warna yang serasi dan harmonis. Model ini memang merupakan salah satu strategi pembelajaran yang bertujuan memberikan pengalaman belajar yang lebih konkret melaui penciptaan tiruan-tiruan bentuk pengalaman yang mendekati suasana sebenarnya dan berlangsung dalam suasana tanpa resiko. Berbagai program open soursces banyak ditawarkan oleh para vendor dalam membuat animasi bergerak yang dapat meniru konten asli dari obyek yang digambarkan diantanya adalah program animasi power point, photoshoop, corel draw, blender dan sebagainya.

${ }^{7}$ Rusman, Model-Model Pembelajaran, Mengembangkan Profesionalisme Guru, h. 302 
b. Teknologi Berbasis Web

Pembelajaran berbasis web yang popular dengan sebutan Web-Based-Education (WBE) atau kadang disebut e-learning (electronic learning) dapat didefinisikan sebagai aplikasi teknologi web dalam dunia pembelajaran untuk sebuah proses pendidikan. Secara sederhana dapat dikatakan bahwa semua pembelajaran dilakukan dengan memanfatkan teknologi internet dan selama proses belajar dirasakan terjadi oleh yang mengikutinya, maka kegiatan itu dapat disebut sebagai pembelajaran berbasis web.

Kemudian, yang ditawarkan oleh teknologi ini adalah kecepatan dan tidak terbatasnya tempat dan waktu untuk mengakses informasi. Kegiatan belajar dapat dengan mudah dilakukan oleh peserta didik kapan saja dan dimana saja dirasakan aman oleh peserta didik tersebut. Batas ruang, jarak, dan waktu tidak lagi menjadi masalah yang rumit untuk dipecahkan.

Bagaimana cara belajar melalui web? Ada persyaratan utama yang perlu dipenuhi, yaitu adanya akses dengan sumber informasi melalui internet. Selanjutnya, adanya informasi tentang letak sumber informas yang ingin didapatkan.

Model pembelajaran dirancang dengan mengintegrasikan pembelajaran berbasis web dalam program pembelajaran konvensional tatap muka. Proses pembelajaran konvensional tatap muka dilakukan dengan pendekatan Student Centered Learning (SCL) yakni melalui kerja kelompok, model ini menuntut partisipasi peserta didik dan pendidik yang tinggi.

Untuk merancang dan mengimplementasikan pembelajaran berbasis web langkahnya adalah sebagai berikut:

1. Sebuah program pendidikan untuk peningkatan mutu pembelajaran di lingkungan kampus dengan berbasis web. Program ini dilakukan idealnya selama 5-10 bulan dan dibagi menjadi 2 tahap. Tahap 1 dilakukan secara jarak jauh dan untuk itu dipilih media web sebagai alat komunikasi. Sedangkan tahap 2 dilakukan secara konvensional dengan tatap muka. 
2. Menetapkan sebuah mata kuliah pilihan di jurusan. Pembelajaran dengan tatap muka dilakukan secara rutin tiap minggu pada tujuh minggu pertama. Setelah itu, tatap muka dilakukan setiap 2 atau 3 minggu sekali. ${ }^{8}$

Belajar dan mengerjakan tugas secara kolaboratif dan kooperatif dalam kelompok sangat dominan pada kedua program tersebut, sehingga kegitan tersebut menuntuk kemampuan dan kreatifitas dosen dalam memberikan bimbingan dan pendampingan dalam melaksanakan tugas yang diberikan kepada peserta didiknya dan oleh karenanya ada 3 alasan mengapa forum tatap muka masih dibutuhkan dalam kegiatan pembelajaran ini. Alasan tersebut adalah :

1. Perlunya forum untuk menjelaskan maksud dan mekanisme belajar yang akan dilalui bersama secara langsung dengan semua peserta didik. Keberhasilan sebuah proses pembelajaran juga ditentukan oleh pemahaman peserta didik tentang apa, mengapa, dan bagaimana proses belajar, dan mengerjakan tugas akan berlangsung.

2. Peserta didik perlu mengetahui keluaran dan kompetensi apa yang akan didapat setelah mengikuti suatu kegiatan pembelajaran. Berdasarkan pengalaman, menejelaskan waktu dan mekanisme belajar merupakan langkah awal yang sangat vital. Kelancaran proses belajar selanjutnya sangat ditentukan pada tahapan ini.

3. Perlunya memberikan pemahaman sekaligus pengalaman belajar dengan mengerjakan tugas secara kelompok dan kolaboratif pada setiap peserta didik. Karena model pembelajaran yang dirancang menuntut kerja kelompok, maka peserta didik perlu memiliki kompetensi dan komunikasi.

4. Perlunya pemberian pelatihan secukupnya dalam menggunakan komputer yang akan digunakan sebagai media komunikasi berbasi web kepada setiap peserta didik. Dengan menyertakan berbagai kegiatan menggunakan komputer beserta fasilitas sistem komunikasi pendukungnya, maka setiap peserta didik harus mempunyai keterampilan mengoperasikannya. ${ }^{9}$

\footnotetext{
${ }^{8}$ Rusman, Model-Model Pembelajaran, Mengembangkan Profesionalisme Guru, h. 337
}

${ }^{9}$ Rusman, Model-Model Pembelajaran, Mengembangkan Profesionalisme Guru, h. 338 
Kegiatan pembelajaran yang berorintasi pada poenggunaan web tidak serta merta menghilangkan peran dosen dalam proses pembelajarannya, justru dengan pendampingan kehadirannya sangat dibutuhkan dalam setiap kali pertemuan tatap muka.

\section{Kesimpulan}

1. Dinamika Penggunaan Teknologi dalam pembelajaran terutama pada lembaga pendidikan tinggi mutlak menjadi perhatian serius bagi para pengelola lembaga pendidikan untuk diimplementasikan, mengingat bahwa semakin maju dan modernya perkembangan teknologi dalam dunia pendidikan dan pembelajaran.

2. Teknologi berbasis komputer merupakan teknoligi terkini yang berkembang seiring dengan perkembangan dalam dunia pendidikan, hampir tidak ada lagi pekerjaan baik administrastif maupun dalam proses perkuliahan yang tidak menggunakan fasilitas komputer

3. Teknologi berbasis web dan e-learning menjadikan pembelajaran di Perguruan Tinggi semakin diminati baik oleh para dosen maupun oleh para mahasiswa sehingga perlu dilakukan pelatihan-pelatihan secara terpadu, integeratif dengan kemajuan teknologi dan penguasaan aplikasi mutakhir dari teknologi tersebut bagi para mahasiswa selaku peserta didik dan dosen selaku pendidinya, dengan dukungan aplikasi diantaranya, e-learning berbasis moddle.com, edmodo.com dan sebagainya. 


\section{DAFTAR PUSTAKA}

Rusman, Model-Model Pembelajaran, Mengembangkan Profesionalisme Guru, Cet. 3; Jakarta: PT. Raja Grafindo Persada, 2011.

Emile Durkheim, The rules of Sosiological Method, New York: The Free Press; 1938.

Robert Heinich, Melonda, M. \& Rossel, J.D, Instructional Technology for Teaching and Learning: Designing Instruction, Integrating Computers an.d Using Media, $3^{\text {rd }}$ Edition Londen: Routledge; 1996. 